\title{
Mirrors and Windows: Teaching and Research Reflections on Canadian Aboriginal Children's Literature
}

\author{
LYNNE WILTSE \\ University of Alberta
}

\section{Abstract}

In this reflective paper, an expanded version of my LLRC pre-conference paper, I draw on thirty or so years of teaching and research experience, augmented by the occasional foray into my childhood, to consider issues of resonance and representation in children's literature. In doing so, I draw on Patsy Aldana's speech, Books that are Windows. Books that are Mirrors. How Can we Make Sure that Children see Themselves in Their Books? Aldana, then President of the Canadian Coalition for School Libraries, delivered her speech to the IBBY (International Board on Books for Young People) Congress in Malaysia, 2008. ${ }^{1}$ As a teacher and now as a teacher educator, I am reminded by Aldana's speech to pay close attention to the children and youth who cannot take for granted, as I was able to, "hear(ing) one's own words, see(ing) one's own face...in a book" (Aldana, 2008).

\section{Books that are Mirrors}

I decided on teaching as a career when I was seven years old, and as an avid childhood reader, I looked forward to sharing children's literature with my future students. During my education degree at the University of Victoria, I took what I considered to be an excellent children's literature course, and headed off prepared (or so I thought) to my first teaching job in a remote predominantly Aboriginal community in the Cariboo-Chilcotin region of the province. ${ }^{2}$ On that note, Patsy Aldana's (2008) comment that "(c)hildren need books that are mirrors in which they can see and learn about themselves, and books that are windows open to the rest of the world" is worth mention. I knew experientially about the second point in Aldana's claim, that literature can "allow readers to imagine beyond the boundaries of their own environment...to broaden their vision of self and their world" (Napoli, 2007, p. 55). And, as much of the literature I read reflected my white, middle class background and experiences, I paid no heed to the first point. During that initial teaching experience I came to better understand the significance of Aldana's (2008) statement. Ingrid Johnston (2010) explains that it is "important to be able to recognize ourselves in a book, particularly if we, as readers, are from a culture that has been marginalized or previously unrecognized in literary texts in the west" (p. 135). This comment describes well the Grades 7 and 8 students who sat before me in my English language arts class, as well as the primary children I worked with in a learning assistance capacity. The lives of these children and youth were not reflected in the commercial anthologies and basal readers I was expected to use. We were two hundred miles on a mostly gravel road from the school board office in Williams Lake, and resources were few. So, I was encouraged to find that one of the required 
novels, Boss of the Namko Drive: A Story from Cariboo Country (St. Pierre, 1965), was actually set in the local area and featured two "Indian cowboys" who took part in an annual cattle drive. I was hopeful that the students would be able to relate to the local setting. After all, Aldana notes that one of the reasons why children need books that are mirrors is the pleasure of seeing one's world in a book. I have felt that pleasure, many times. Unfortunately, in this case, the experience was anything but pleasurable. Rather, much to my chagrin, this book served to further marginalize Aboriginal culture, as can be seen in the following excerpt, as one of the ranch hands warns the young boss what to watch out for: "'I tell you, kid, never trust the Indians with liquor. It don't act on them like a white man. Remember that. One ounce...'-he would hold rough thumb and forefinger an inch apart-'one ounce and they're away. They can't handle their liquor."' (p. 66). That the main character tried to defend the Indian cowboys, or that these characters helped to save the cattle drive in the end did not seem to matter-with that depiction, the damage was done, at least in my inexperienced view. I can recall lying awake at night, dreading the class we would read this, and other sections. As a beginning teacher, I did not know how to address the generalizations and racism inherent in the text, nor how to bring my discomfort into the open with my students. That some of my students' families struggled with alcohol abuse aggravated my dilemma, as I did not know how to tackle that topic either. Accompanying the reading of the dreaded words were awkward silences. More than thirty years later, I still cringe with shame at the memory. I expect this is why I reacted so strongly to Aldana's question, "What is the long term effect on a child of a steady diet of books from which he is totally absent or present but falsely depicted?" I was facing a class populated with examples. It is why, although my childhood was enriched by reading books as windows, I agree with Aldana's argument "that our priority today must be for books that are mirrors" (para. 28).

Naturally, it is not only Aboriginal students who need to be able to see themselves represented in the books they read. In the 30 years since my first teaching job, Canada's population has changed dramatically, with more than 200 different ethnic origins reported in the online report, Canada's Ethnocultural Mosaic, 2006 Census (Statistics Canada, 2008). Joyce Bainbridge (2010) notes that if current population trends continue, "Canada's visible minority population will continue to grow much more quickly than the non-visible minority population" (p. 97). In addition to a surge in immigration, Aboriginal population is also on the rise. The significance of this is that if teachers do not consider cultural diversity in relation to text selection, an increasing number of students will not recognize themselves in the Western literary canon. Fortunately, over the past three decades, there has been an upsurge in texts authored by immigrant and firstgeneration Canadians, as well as increased publication of children's literature by authors of Aboriginal heritage.

After twelve years teaching in small Aboriginal communities, I had the opportunity to revisit Aldana's (2008) statement in a broader context when I moved to an urban centre to attend graduate school. As a research assistant, I worked on a project with two professors who had been asked to assist with updating the library collection in a culturally and linguistically diverse school. We began by conducting a survey of the school library. Although $90 \%$ of the student population was non-white, with many immigrant students from Asian, African and South American countries, for the most part, 
the library collection reflected the middle class white nuclear family, typical of books from my childhood. Project funds allowed us to provide two Grade 7 classes and one Grade 3 class in the school with a contemporary set of multicultural picture books and novels. I interviewed a number of the Grade 3 and Grade 7 students about their preferences after they read the books. In a chapter entitled, Sites of Discovery and Discomfort: Reading and Teaching Multicultural Literature, Johnston (2000) discusses the study results. A number of research participants chose characters from the same ethnic background as themselves. For example, Kari, ${ }^{3}$ one of the students I interviewed whose family came from Vietnam, chose Rainbow People by Laurence Yep (1989), a collection of Chinese folktales told by immigrant workers, "because I'm sort of Oriental, too" (p. 140). She also chose Paul Yee's Ghost Train (1996), a historical account of the dangers Chinese immigrants faced in building Canada's railways because aspects of the book "reminded me of things I do at home, like the incense" (p. 140). Johnston (2010) cautions us that this type of recognition may be more complicated than it first appears. For teachers who are wondering whether they should choose books that somehow "represent" the cultural backgrounds of their students, Johnston (2010) explains that good multicultural literature can provide "this sense of familiarity when the characters and setting are outside our own familiar milieu" (p. 135). Johnson's point about the complexity of recognition proved provocative when I interviewed Ruby, one of the Grade 3 students in the study, and the one Aboriginal student in her class. Students were asked to bring one or more of their favourite texts from the new collection to the interview; one of the questions asked for an explanation of choice. Ruby brought three texts to the interview. Interestingly, to me at the time, the books she brought were the three books in the collection that could be considered Aboriginal literature. When asked why she had chosen the books, Ruby had a clear reason for each: she chose a biography of Chief Dan George because she liked true stories; My Kokum Called Today (Loewen, 1993), in which a Cree girl from the city goes to the reserve to visit her grandmother, was selected because it reminded her of her grandmother; her third choice, an Aboriginal legend, was picked for its style of art which featured an intricate border design. In retrospect, I realize that I should not have just assumed that Ruby chose these books because of their Aboriginal content. In this regard, Dudley-Marling (2003) cautions teachers to not assume that there is a complete alignment between the reader and the cultural representation. Nevertheless, I still feel that Ruby was drawn to these particular books because she recognized aspects of her life within the stories and artwork, making that sense of familiarity that much stronger. And, given my prior teaching experiences in Aboriginal communities, I found her choices compelling.

Over the years since I met Ruby, I have witnessed the effect of contemporary Aboriginal literature on many students, as well as pre-service and in-service teachers. The story of Geneva is the most memorable. An Aboriginal student in my language and literacy course in a small teacher education program in the interior of British Columbia, Geneva participated in a research project, Preservice Teachers' Perspectives on Canadian Identity and their Understandings of Ideology in Multicultural Picture Books . 4 As part of the study, the research participants were to select a book, from a collection of more than 70 texts, which they would use as the basis to plan and teach a lesson to children during their field experience. Geneva chose Two Pairs of Shoes (Sanderson, 
1990), a story about an Aboriginal girl who receives two pairs of shoes for her birthday-a patent leather pair she had been coveting and a pair of beaded hand-made moccasins from her grandmother, who tells her that she must learn when and how to wear each pair. With Geneva, I have no doubt that this text provided "cultural affirmation...through exposure to main protagonists that share the same culture as the reader" (Loh, 2009, p. 293). In the following interview excerpt, Geneva, who was adopted by a white family at age three weeks, describes her strong personal connection to the book:

I made that choice because that's what I feel like my life was. The way I grew up is I always had the patent leather shoes and everything I needed. But, when I met my First Nations family when I was fourteen I started learning about moccasins and tanning, moose meat drying and smoking fish. And, that was very difficult for me because by that time all my cousins had been doing that for many years, so I was made fun of, called a red apple, white on the inside, red on the outside. (Geneva, student teacher interview, 05 March, 2007)

At this point in the interview, Geneva was overwhelmed with emotion and had to stop. When she was ready to continue, she had a bit more to say as to why the book spoke to her so strongly: "As soon as I read it I knew exactly what it was all about." She elaborated:

No, it's ok, I had to cry. I went to my grandmother, who I had known then for a year or 2, because I was so sad. I told her that I didn't know any of these things and she just hugged me and said, "it's OK. I knew you'd come back to us." And, she said, "you know the white man's world and now we'll show you the Indian world. And, one day our people will come to you for help and since you know the white man's world you'll know how to help us." She made all the frustration go away, the not knowing my language or not knowing my people. So this book, I picked it because it was my world. (Geneva, student teacher interview, 05 March, 2007)

Geneva then went on to describe how, as part of the lesson she taught, she brought in artefacts from her Aboriginal heritage to share with the students. The following excerpt provides an example as to the "sense of familiarity" that multicultural literature can provide.

There was one boy whose eyes lit up when I brought my baby basket, beaded earrings and deerskin vest. He was so excited to tell me that his step-mom has one of those baskets, and could he bring it. He was so proud that he could contribute to the lesson. And, other students, like Indo-Canadian, talked about their cultural backgrounds. So, this lesson was important, not just in the First Nations component, but in having students explore different aspects of their identity. (Geneva, student teacher interview, 05 March, 2007) 
Geneva's comment is a reminder that "individuals engage in multiple identity practices... and they are able to move from one identity to another" (Bucholtz, 1999, p. 209). Two Pairs of Shoes was one of many texts in the collection that invited students to "explore self in relation to others in specific contexts, including those of ethnicity, gender, social class and nation" (Loh, 2009, p. 289).

As I listened to Geneva tell her story, my thoughts returned to the first day of the class in which we met. In my introduction, I mentioned my first teaching job, and the profound impact it had had on my teaching career. After class, Geneva waited to speak with me; she told me that her father was from the same community and wondered if I knew any of her family members. Following a short exchange, it became clear that I had taught her uncle. In fact, Carter was in the class I wrote about at the beginning of this paper. Geneva brought a photo of her uncle, his wife and two children to our next class. As I looked at the photo, my feelings were mixed. I felt reassured to see my former student, one of 14 children, with his own family, looking so well. At the same time, the photo reminded me of the ineptitude I felt as a teacher in a cross-cultural context for which I was so poorly prepared. Delpit (1988) points out that communicating across cultures takes a special kind of listening that can be painful "because it means turning yourself inside out...and being willing to see yourself in the unflattering light of another's angry gaze" (p. 297). I do not recall that Carter's gaze, in particular, was angry; the light was nevertheless unflattering, and rightly so. Over the next two years, in the three courses she took with me, I introduced Geneva to other books in which she was able to see aspects of her life reflected, for example, This Land is My Land, George Littlechild's (1993) autobiographical account of the struggles his family endured through many generations, as well as books which functioned as windows, providing glimpses of life in faraway places, such as The Heaven Shop (Ellis, 2004), about AIDS orphans in Malawi. Geneva is now a teacher at the new(ish) band-operated school in the community she left as a baby and returned to as a teenager. In many ways, her grandmother's prophecy has come to pass. Well educated (in the school sense), Geneva has much to offer her students; they have something she never had-exposure to their own culture and language from an early age.

Aldana (2008) addresses the subject of language in her speech, noting that "(p)eople who speak minority languages are doubly disadvantaged." This applied to many of my first students, in particular those who lived 'downriver' from the main community and had to stay in residence to attend school. These children, who spoke Carrier as their first language, began school in Grade 1 with little if any knowledge of English. In my role as learning assistant, I worked with primary students who were behind in reading, according to expectations of the school district. While I will never forget the irrelevancy of the required basal readers to the children's lives, at the time I did not adequately understand the significance of Aldana's question: "If learning to read has to happen in a language that is not your own, where does that leave you?" However, a number of students in the school were less fortunate; due to the legacy of residential schooling, when speaking Aboriginal languages was forbidden, Carrier, the mother tongue, had not been passed on. In the following interview excerpt, Richard Van Camp, an Aboriginal author and storyteller, explains the impact of residential school language policies on his family in the Northwest Territories: 
My mom went to a residential school for twelve years, so we were never really taught our language...To this day I think that was one of the single biggest mistakes that every family made in the north....at 37 years (now), there's nothing more that I want for myself than to learn Dogrib. (Van Camp, Courtland, \& Gambell, 2010, p. 155)

Fortunately, as the school in which I taught had a Carrier language program, the students had the opportunity to at least begin to learn their 'lost' language. There were almost no reading resources in the language, though. For someone like me, who grew up surrounded-at school as well as at home-by texts in English, it is difficult to imagine trying to learn to read in a language in which there were few, if any, children's books. Needless to say, this absence was one of many factors in why many of these students were less than successful in school by mainstream standards. Accordingly, I have been encouraged, in recent years, to see the publication of books in various Aboriginal languages as well as bilingual books (with accompanying text in English or French) that have the potential to support Aboriginal language maintenance and/or revival (as well as reading). Select examples include Tomson Highway's Songs of the North Wind trilogy (2001, 2002, 2003), written in Cree and English; Someone Smaller than Me (Cooper, 1993), with text in Inuktitut and an English translation at the end; and Byron through the Seasons (Children of LaLoche \& Friends, 1990), a Dene-English book with text in English and Chipewyan. Hopefully, these books can play a role, however small, in repairing the damage to Aboriginal languages caused, in large part, by residential schooling.

Given the prominence of English as a global language, Aldana's (2008) question about people learning to read in a language not one's own has broader implications:

Perhaps they live in a poor country of diverse people whose only common language is the one inherited from the former colonial power as is true in so many parts of Asia, Africa and Latin America. Their only commonality may be an imported language. They may never find their own language in their books....This puts minority language people at an almost fatal disadvantage.

Her words called to mind a powerful childhood memory:

My dad was a high school teacher and on weekends when he needed to go to school to catch up, I would sometimes accompany him. On these occasions, he would often give me tasks to do. Just once was the task memorable. I was presented with a large box of used texts. My dad explained that I was to go through the box of books and create two piles, one for the texts that were in decent shape and another for those that were somewhat damaged. He provided me with a couple examples of each so that I would have a baseline for judgment. What I was told is that the texts in the 'good shape' pile would remain at the school for students' use, while the 'discard' pile would be sent to poor students in Africa who didn't have textbooks. I cannot remember the exact wording of my dad's instructions, but my mission was 
clear. Being such a lover of books and reading, it was hard for me to imagine children who were so unfortunate as to not have their own books. My dad returned to his classroom, leaving me alone. With some of the books, my job was easy; they were either in good enough shape to be 'keepers, 'or they had enough damage that I could justify putting them in the 'for Africa' pile. However, there were a number of books where my decision was not so obvious. With these questionable texts, I found myself rooting for the Africa pile. However, as a very literal 10 year old, it was hard for me to not follow my dad's instructions exactly-I felt that I needed to make sure they qualified. I actually did damage to some of the books, a tear here, and a scribble there. I can hardly believe it now, especially as I was a child who found it hard to tolerate damage of any sort. This shows how determined I was that more children in Africa would get books to read! When my Dad returned, that pile was higher than the good enough for Canadian students pile. And, I was quite pleased with my good works.

Many years later, as a graduate student taking courses for a degree in International and Intercultural Education, I learned much about theories of development, colonialism, oppression and dependency. The memory of defacing books surfaced to fill me with extreme embarrassment, as the inappropriateness of my childhood good works, however well intentioned, became clear. I expect that my most important learning, though, was the realization that it was one thing to think about colonialism in a distant country such as the Africa of my childhood imaginings; it was quite another to recognize my own country in this way. Donawa and Fowler (2013) make the point: "Canadians have had to acknowledge a history blighted by their own devastating colonization of Aboriginal societies..." (p. 62). This is why the discussion of indigenous texts and publishers in Bradford's (2007) Unsettling Narratives: Postcolonial Readings of Children's Literature, struck a chord. Bradford explains that, in the settler societies of Australia, Canada, New Zealand and the US, "access to publishing houses favours those for whom English (and in francophone Quebec, French) is their first language, and the minority status of Indigenous readerships ensure that mainstream publishers produce relatively little Indigenous writing except that which can readily be marketed to non-Indigenous readers" (p. 46). As a nonAboriginal person in a settler society, I need to pay closer attention; simply noting that books are being published by Aboriginal authors and/or in Aboriginal languages, as I have here, is not enough. I was dismayed to read how the "processes of selection, translation, editing and marketing typically shape Indigenous texts into mainstream products" (Bradford, p. 46). Bradford points out that there are notable exceptions. For example, Van Camp speaks to the difference that Canadian Aboriginal publishing houses can make: "What that means is you have access to Aboriginal editors, Aboriginal publishers, Aboriginal book designers. I find that when you work with an Aboriginal publisher, there's more of a partnership" (Van Camp, Courtland, \& Gambell, 2010, p. 170). I have learned to appreciate that it is against a "heavy colonial and neo-colonial history" that Aboriginal authors writing for children have had to "adapt and redefine this Western literary form to tell their own stories" (Wolf \& DePasquale, 2008, p. 90). With Jingle Dancer (Smith, 2000), a picture book about a girl who dreams of jingle-dancing like her 
grandma, the author has provided an example of a text which has been successful in doing so:

What distinguishes Jingle Dancer from the vast majority of settler society texts is that it treats as normal and natural Jenna's aspirations and the values of her culture. In this way, it offers Native readers the kind of narrative subjectivity taken for granted by the white children who are the implied readers of most children's literature, while positioning non-Indigenous readers as outsiders to a culture that they may imaginatively comprehend but that is marked by difference.

(Bradford, 2005, pp. 45-46)

After reading Bradford's explanation, curious to see what she meant, I found a copy in the library. It so happened that, as part of a research project, Creating Third Spaces for Minority Language Learners in a School-University-Community Research Collaboration, I had interviewed a young Aboriginal girl, Karina, who had completed a Heritage Fair project on jingle dress dancing. ${ }^{5}$ In the following interview excerpt, she explains its significance.

Well, I picked this topic because I myself am a jingle dress dancer. I'm a junior princess. My responsibility is I have to go to as much powwows as I can and when I put my crown on I have to be all proud. When I dance it makes me feel good since I know I'm gonna dance for the people. It's like, not a competition to me, it's just the way I dance and that's why I picked this dress... It is a healing dress because there's a story about a man who was very ill, and he had his sickness broken because he had a vision about this dress. And, it's called the jingle dress because of the tobacco lids and whenever you hear that it's like a ring going on a tin thing. (Karina, student interview, 12 June 2008)

Had I known about this book at the time, I would have recommended it to Karina: it would have been perfect for her project. More importantly perhaps, Jingle Dancer would have given Karina, as an insider to the culture, exposure to that sense of narrative subjectivity which many mainstream readers, myself included, have taken for granted countless times.

\section{Books that are Windows}

As shown, my teaching and research experiences have repeatedly reinforced Aldana's (2008) point that "our priority today must be for books that are mirrors (para. 28)." Still, Aldana notes that "(n)one of what I have said means that I don't believe that the other side of the metaphor also applies (para. 37)." I concur; of course, children also need books that are windows. While Geneva's experience, for example, is illustrative of the significance of cultural affirmation, responses to Aboriginal literature from other students and research participants demonstrate that "from cross-cultural perspectives, exposure to literary texts about other cultures allow for the imagination of a world where self exists in relation to other" (Loh, 2009, p. 293). A pertinent example can be found with Erica, who participated in the same research project as did Geneva. In the 
following interview excerpts, Erica-white, middle class, born and raised in the lower mainland of British Columbia-describes how the books she read about Aboriginal people as a child yielded a very limited view:

As a young child, I often chose to read historical settings, like Little House on the Prairie from pioneer days, and I really romanticized the whole First Nations culture. I was very unaware that there was a difference between then and now. In high school, I had very few Aboriginal friends, so nothing bridged me to reality. I guess you could say I was very much infatuated with the old days. (Erica, student teacher interview, 17 May 2007)

Books like Little House on the Prairie (Ingalls Wilder, 1953), written from a white perspective, enabled Erica (and countless other readers) to remain infatuated with the past. In The Truth about Stories, Thomas King (2003) explains that what Native writers discovered was that the North American past that had been created by the dominant culture "was unusable, for it had not only trapped Native people in a time warp, it also insisted that our past was all we had" (pp. 105-6). When Erica decided to become a teacher, she acknowledged that her childhood impression of First Nations culture had little to do with contemporary reality:

But when I decided to get into the field of education, I realized I'm likely going to teach in a small community with First Nations students. It started to make me aware of what has happened since then, and to think about the First Nations who were in my mind growing up and the real children who would be in my future classrooms. I had to fill in the blanks. So, with this project, I gravitated towards a lot of the books with First Nations content. (Erica, student teacher interview, 17 May 2007)

Was there children's literature in the study collection that enabled Erica and her classmates to begin to "fill in the blanks" when it came to Aboriginal people and issues? Wolf and DePasquale (2008) explain that, unlike Native literature for adults, which tends to be protest literature, children's fiction notably avoids the portrayal of the "inequities still all too prevalent in many Aboriginal communities in contemporary Canada" (p. 91). With picture books for children "the pressures to produce... positive images of Nativeness come from the history of colonization and a desire to counter the contemporary stereotypes of the drunken, lazy, or promiscuous Indian, or the historical ones of the bloodthirsty warrior, Noble Savage or seductive Indian maiden" (p. 92). Select books in our collection that provide contemporary "positive images of Nativeness" included Morning on the Lake (Waboose, 1997), which describes a canoe trip for an Ojibway grandfather and his young grandson, and My Kokum Called Today (Loewen, 1993), which celebrates the relationship of an urban Aboriginal girl and her grandmother who lives on a reserve. While texts such play a crucial role in countering negative stereotypes, they fail to address the ugly historical issues or the challenging contemporary problems that have resulted from past injustices. Littlechild's (1993) This Land is My Land, does both. In a chapter entitled Red Horse Boarding School, he 
describes the cruel reality of residential school and recounts the devastating effects that linger. Clearly, This Land is my Land provides an exception to "general expectations of age appropriateness" and the "assumption that children's innocence should be protected" (Wolf \& DePasquale, 2008, p. 92); in doing so, it expands the view out the window. Van Camp takes on the question of the age appropriateness of Littlechild's text: "The big question is, is that a kid's book? And yes, it is, but it's also a testimony to the resiliency of Aboriginal people and what we've had to face" (Van Camp, Courtland, \& Gambell, 2010, p. 168). Erica can envision a place for This Land is My Land in the elementary classroom, albeit with older students. As a volunteer judge for the Heritage Fair competition, Erica met Philipa, a Grade 4 student who won an award for her project, Locked up Indians. As Philipa had interviewed both her grandmothers about their experiences at two different residential schools in the interior of British Columbia, Erica saw Littlechild's book as an ideal reference:

Well, I'm fairly certain that somebody would have introduced This Land is My Land to her knowing the topic. I think this would have gone beautifully with her presentation, having to deal with her two grandmothers having such differing experiences with residential schooling. I think that this could have helped her bridge between the two. I think books like George Littlechild's This Land is My Land have their place in saying this is an important issue, let's talk about it now. (Erica, student teacher interview, 17 May 2007)

I had the opportunity to interview Philipa about her Heritage Fair project as part of the Creating Third Spaces for Minority Language Learners in a School-UniversityCommunity Research Collaboration research project. I asked her to tell me about Locked up Indians:

Before I did my project, I didn't realize residential school was that big of a deal. But, as soon as I chose the topic, my dad's like, "Wow." There are a lot of people around here to interview about residential school, but I decided to interview both my grandmas, because both of them went to different residential schools... I learned that they had to cook and clean and they were separated from their parents and punished for being different. And, they weren't allowed to speak their native language. (Philipa, student interview, 13 June 2008).

Undoubtedly, This Land is My Land would have been an excellent resource for Philipa as she did research about residential schools for her project. Littlechild informs the reader:

For many years, up through the 1960s, the government took Indian children away from their families and forced us to live in boarding schools. In these places we "Red Indians" as we were called were educated in the white man's way. The teachers forced us to learn English and become Christians. They cut off our braided hair, they beat us if we spoke our Indian languages. We suffered much cruelty and abuse. (p. 18) 
Recently, I had the privilege of attending the final event for the Truth and Reconciliation Commission on Residential Schooling (TRC), held in Edmonton. One of the goals, posted on the TRC website, is to "acknowledge Residential School experiences, impacts and consequences." Words to adequately express the impact of bearing witness to these proceedings fail me; as Philipa learned, though, I can say that residential schooling was indeed a big deal.

Another example as to how children's literature can play a role in helping to achieve the goal of the TRC can be found in a follow-up study to the picture book research, Engaging Teachers with Canadian Literature for Social Justice. Project funds provided participating teachers with the opportunity to select a class set of contemporary Canadian texts for their students to read. In inquiry groups, teachers discussed pedagogical strategies for teaching these texts in ways that would engage students in reflections on structural and social inequities in Canadian society and allow considerations of what it means to be Canadian in diverse cultural settings. It struck my research assistant and I that, in our inquiry group of ten teachers, five chose Fatty Legs: A True Story (Jordan-Fenton \& Pokiak-Fenton, 2010), a memoir about an Inuit girl, Olemaun, who attended residential school in the Northwest Territories, to read with their students. Several of the teachers in our research project questioned why they had not learned about this topic when they were in school, and were determined that this will not be the case with their students. For instance, in Collette's multicultural Grade 6 class, Fatty Legs was one of four texts read as part of a thematic group advocacy approach. A group of three boys-Timmy, Sheldon and Larry-chose Fatty Legs. The teacher scheduled times for students to meet during their reading of the text. She noted that "...when they started talking to each other, that was the best part. We worked on how do you discuss a novel, what do you say?" Collette provided students with sticky notes to record the questions they had as they read:

"What does it mean when they cut Olemaun's hair?" was what Larry wrote. And one of the boys in his group, Timmy, had the answer. I just listened. Timmy figured it out because he is a deep thinker. He's like, "well it's about power, it's about control, it's about taking away their Indian." He really caught onto that idea of breaking the Indian out of them. (Collette, teacher, 15 August 2012)

Following the reading of their texts, each group had to identify a social justice issue within their book and create a non-profit, non-governmental organization that would back the issue and present their solution or their action in a 'pitch for funding.' Not surprisingly, the issue identified by this group was that of residential schooling. Collette explains their task:

They had to find out the background information about residential schooling, and then research what has been done to this point to resolve or to bring justice to the issue, followed by a plan of what would they do now. They had a mind map where they brainstormed solutions, and from those, as a group they had to choose what they would do about the issue. What the boys came up with is that you can't do anything about residential schooling; it's done. So, their question was, "How 
do we repair, how do we heal, what action can we take at this point? One of their ideas was to turn old residential schools into healing centers and museums. (Collette, teacher, 15 August 2012)

Galway (2008) emphasizes this relationship between the past, present and future in literature for children: "This connection between the past and the present makes the manner in which a nation communicates its history to children, who represent the present and the future, particularly significant" (p. 115). Texts such as Fatty Legs offer a means for children and youth to explore historical perspectives, and to make a difference today and tomorrow. As Galway notes, how we teach our history to children matters. To date, the students in our project who have read Fatty Legs have been both engaged and, to a degree, enraged by the text. They tried to imagine what they would feel like had they been in Olemaun's position, and they found it hard to believe that a child their age experienced such mistreatment in Canada. Students' responses reveal the potential of these books to interrogate "notions of a homogenous sense of nation" (Johnston, Bainbridge, \& Shariff, 2007, p. 75).

\section{My Mirrors are Your Windows}

In the section of the paper, I consider Aldana's (2008) observation that "my mirrors are your windows and vice versa" (para. 37). I return to Fatty Legs to make this point. As mentioned, most of the students in our project experienced this text as a window into the past. But, for a number of these students, there was a glimmer of a reflection-Timmy, for example. Collette explains: "It touched him, this story, and he and his father went out to Blue Quills (Albertan Indian Residential School) and looked around. Timmy started finding out that there were residential school survivors in his family." Apparently, prior to the project, this topic was not spoken about at home; the reading of Fatty Legs provided an opportunity to break long-held silences, for Timmy and other students.

To assist Timmy and his group members with their research into residential schooling, the three boys invited the Program Coordinator for FNMI (First Nations Métis Inuit) Education with the local school district to the school. As an Inuit woman from the Canadian Arctic, the Program Coordinator was able to provide the students with invaluable background knowledge related to the memoir. Collette explained that she also encouraged them to go beyond the text by doing "something local to reflect their school's diversity."

We're sitting in the library and she says: "Look around. Do you see any books with you on them?" as we had a Métis and a Cree in the group. They're like, "no, there are none." And she said that maybe that's a place to start. So, she donated FNMI books to the school and they created a culture corner. They put a mirror up which said something like, "See yourself here in these books." (Collette, teacher, 15 August 2012)

The connection to Aldana's argument is obvious here. However, Aldana is one of many to utilize this metaphor. For example, in a blog post, Turning Mirrors into Windows, 
Superintendent Karen Schulte (2012) draws on journalist Sydney J. Harris, who is quoted as saying, "The whole purpose of education is to turn mirrors into windows." On one level, her response makes sense: "When you gaze into a mirror, the only things you see are your reflection and a limited area around you. However, when you look out a window, the view can be almost endless." But, when I think of my first students and the many other students who may never have seen their reflection in the texts they are given to read, I understand Aldana's argument to prioritize books that are mirrors. I anticipate that if more children and youth were able to read books in which they could see and learn about themselves, they may then be more likely to embrace books that are open windows to the rest of the world. I am cautiously optimistic. As mentioned, there now exists authentic Aboriginal literature for children and youth, as well as a range of texts that show other non-mainstream representations.

\section{Doors}

In their work on children's literature, Botelho and Rudman (2009) extend the use of the mirror and windows metaphor to include that of the door: "Mirrors reflect our language use and windows afford expanses to new understandings, whereas doors invite action" (p. 265). This is why my optimism is tempered. Despite availability, for various reasons, too few teachers are actually using literature of this nature with their students. This was, in large part, the impetus for Ingrid Johnston (principal investigator) and I to conduct a pilot project to the Canadian Literature and Social Justice study. Research shows that while many Canadian teachers acknowledge the value of having their students reading Canadian literature, their preference is to teach the same familiar canonized texts, in particular British and American literature (Bainbridge, Carbonaro \& Green 2005; Johnston 2003; Mackey 2009). In addition, teachers often base their literary selections on their own reading histories, on the availability of texts in their schools, and/or on provincial curriculum mandates and guidelines (Baird, 2002). Our study findings confirmed the research in the field. ${ }^{6}$ For example, Terry, one of our teacher participants, chose Monkey Beach (2001), by Aboriginal author Eden Robinson, to teach to her Grade 12 students; this was clearly a departure from her usual practice:

Admittedly, I am a very sheltered English 30 teacher, and I am looking to break out of the typical canon....Because this opportunity has forced me to get new books for my class, I am going to do Monkey Beach by Eden Robinson for the simple fact that I am trying to break away from Pride and Prejudice and the other books that have been so dictated in my school. (Terry, teacher, inquiry group transcript, 25 January 2011)

An additional factor in our study regarding text selection proved to be teachers' comfort level with teaching unfamiliar, and in some cases, 'difficult' texts. Much of the literature to which we introduced the teachers in our study paid critical attention to such historical and political factors as colonialism, indigeneity, immigration, and cultural policies; these topics have the potential to bring forth 'difficult knowledge', which Pitt and Britzman (2006) maintain may include "narratives of historical traumas such as genocide, slavery, and forms of social hatred and questions of equity, democracy 
and human rights" (p. 379). Monkey Beach, which confronts such issues as oppression, the residual effects of residential school, and Native rights, was no exception. This choice of text positioned Terry, who taught in a rural school within the Catholic school district, out of her comfort zone: "Content was concerning-I teach in a Catholic school. I did worry a bit about the sex, drugs, accusations regarding priests, etcetera. However, I pushed through." As our study progressed, we turned to Boler and Zembylas' (2003) notion of a 'pedagogy of discomfort,' which recognizes and problematizes the daily habits and routines that are largely shaped by dominant values and assumptions and highlights gaps and absences in current curricular practices, to help us theorize our research findings. The text caused her students some discomfort as well; they struggled, in particular, with the ambiguities in Monkey Beach. Boler and Zembylas (2003) explain that

(i)nhabiting this ambiguity can be very discomforting and demands substantial negative emotional labor such as vulnerability, anger, and suffering. To tolerate this ambiguity, one has to dismantle old habits and replace them with new ones and this involves considerable emotional and intellectual risk. However, emotional labor in the context of inhabiting ambiguity can produce favorable results, including selfdiscovery, hope, passion and a sense of community. (p. 129)

With the support of the inquiry group, Terry was able to work through her discomfort in teaching an unfamiliar text, and to support her students as they tried to make sense of a novel they found difficult. A measure of the "favourable results" to which Boler and Zembylas refer occurred in Terry's class: "I am breaking out of my comfort zone. It's uncomfortable but in that uncomfortable moment you grow." Involvement in the project had given Terry what she needed to walk through the door.

\section{Conclusion}

It is perhaps not surprising that this discussion of teacher discomfort takes me back to the traumatic teaching experience I described at the start of this paper. When I taught Boss of the Namko Drive, the discomfort was plentiful, the positive results few. In closing, I return to that time and text. I wonder how I would teach the text differently. My first thought is that over many years of teaching, often in challenging contexts, I have learned to be comfortable with discomfort, and I am no longer afraid to disrupt silences. I have learned as well ways to support my students with discomfort and difficulty. Boler and Zembylas (2003) make the point that "(d)ifference is produced not only through an explicit naming but also through the power of silence and absence" (p. 120). As both naming and silence marked my teaching of the novel, I feel that these changes would make a difference. Although I failed miserably at the time, I am now confident that I would be able to lead discussions around Boss of the Namko Drive that would help my students to recognize the "multiple, heterogeneous, and messy realities of power relations as they are enacted and resisted in localities...(Boler \& Zembylas, 2003, p. 131). I recognize that I make this statement with the benefit of years of teaching and research experience, informed by a wide range of academic literature. Contemporary theories of social justice that see teachers as agents of social change attending to issues of race, class, 
gender and language (Cochrane-Smith, 2004; McDonald, 2007) and studies that emphasise the role of literature in advocacy research in literacy education (Bender-Slack, 2010; Cherland \& Harper; 2007; Ching, 2005; Wolk, 2009) have provided me with academic knowledge and pedagogical strategies that I lacked at the time.

In this regard, a critical multicultural analysis approach (Botelho \& Rudman, 2009), which presupposes an understanding of sociopolitical contexts, would suit particularly well. At the heart of a critical multicultural analysis approach is the authors' view that the teaching of literature should begin with social justice. For teachers who are committed to socially just teaching, Botelho and Rudman pose the following questions: "What texts and reading practices do we privilege in our classrooms? (p. 269). Regrettably, the reading practices that were privileged in my language arts class did not do justice to socially just teaching. Botelho and Rudman explain that "critical multicultural analysis challenges fixed and bounded notions of culture, identity, class, race, gender and power, and makes visible the social construction of culture, power..." (p. 260), thus providing a way to analyze how dominant ideologies function in text and images. Boss of the Namko Drive was rife with opportunities to examine power relations: Why was a 15-year old white boy appointed boss of the cattle drive? Why were the "Indian" characters portrayed as uneducated and likely to get drunk? Why were there no women on the cattle drive? Rather than scaffolding my students' understanding of power relations in a critical reading of the text, I assigned them the comprehension questions that the district supplied in the teaching manual.

As for the Botelho and Rudman's other question-what texts we privilege in our classrooms?-I doubt if I would choose to teach this text now. At the time, the expectation from the school board that the same resources be used throughout the district (which was large in area and diverse in population) was rigid. Plus, the choices in our rural, isolated school and community were very limited. Furthermore, despite having taken a children's literature course during my teaching degree, my knowledge of culturally appropriate Aboriginal literature was also limited; such selections were not on the course reading list. For the students who will sit in future classrooms, I make sure they are on mine. As Van Camp notes: "That's where multicultural and Aboriginal literature comes in...if people can see themselves in the literature, and they feel welcome in the classroom because of what has been taught in there in a good way, you can't lose" (Van Camp, Courtland, \& Gambell, 2010, p. 170). On this point, there is no doubt that my first students lost out. It is my hope that Aboriginal students in current and future classrooms will be on the winning side of hearing their own words and seeing their own faces in the texts they are given to read in our Canadian classrooms.

\section{References}

Aldana, P. (2008). Books that are windows, Books that are mirrors: How we can make sure that children see themselves in their books [Speech transcript]. Retrieved from http://www.ibby.org/index.php?id=1008

Bainbridge, J. (2010). Canadian multicultural picture books for young adolescents. In M.C. Courtland \& T. Gambell (Eds.), Literature, media \& multiliteracies in adolescent language arts (pp. 79-102). Vancouver: Pacific Educational Press. 
Bainbridge, J., Carbonaro, M., \& Green, N. (2005). Canadian children's literature: An Alberta survey. Alberta Journal of Educational Research, 51(4).

Baird, J. (2002). English Language Canadian literature in high schools, Toronto: Writers Trust of Canada. Available January 23, 2006 from http://www.canadacouncil.ca/publications e/research/di127234254927656250.ht $\mathrm{m}$

Bender-Slack, D. (2010). Texts, talk ... and fear? English Language Arts teachers negotiate social justice teaching. English Education, 42(2), 181-203.

Boler, M., \& Zembylas, M. (2002). Discomforting truths: The emotional terrain of understanding difference. In Trifonas, P.P. (Ed). Pedagogies of difference: Rethinking education for social change (pp.110-136). New York \& London: RoutledgeFalmer.

Botelho, M., \& Rudman, M. (2009). Critical multicultural analysis of children's literature: Mirrors, windows, and doors. New York: Routledge.

Bradford, C. (2007). Unsettling narratives: Postcolonial readings of children's literature. Waterloo, ON: Wilfrid Laurier University Press.

Bucholtz, M. (1999). "Why be normal?": Language and identity practices in a community of nerd girls. Language in Society, 28, 203-223.

Cherland, M., \& Harper, H. (2007). Advocacy research in literacy education: Seeking higher ground. Mahwah, N. J.: Lawrence Erlbaum.

Ching, S. H. D. (2005). Multicultural children's literature as an instrument of power. Language Arts, 83(2), 128-136.

Cochran-Smith, M. (2004). Walking the road: Race, diversity, and social justice in teacher education. New York: Teachers' College Press.

Delpit, L. (1988). The silenced dialogue: Power and pedagogy in educating other people's children. Harvard Educational Review, 58, 280-298.

Donawa, W., \& Fowler, L. (2013). Reading Canada: Teaching Canadian fiction in secondary schools. Don Mills, ON: Oxford University Press.

Dudley-Marling, C. (2003). "I'm not from Pakistan": Multicultural literature and the problem of representation. In D. Fox \& K. Short (Eds.), Stories matter: The complexity of cultural authenticity in children's literature. Urbana, IL: National Council of Teachers of English.

Galway, E. (2008). From nursery rhymes to nationhood: Children's literature and the construction of Canadian identity. London, UK: Routledge.

Johnston, I. (2000). Sites of discovery and discomfort: Reading and teaching multicultural literature. In Barrell, B. \& R. Hammett (Eds.), Advocating change: Contemporary issues in subject English (pp. 136-146). Toronto: Irwin.

Johnston, I. (2003). Re-mapping literary worlds: Postcolonial pedagogy in practice. New York: Peter Lang.

Johnston, I. (2010). Multicultural novels for the Canadian classroom. In M.C. Courtland \& T. Gambell (Eds.), Literature, media \& multiliteracies in adolescent language arts (pp. 133-152). Vancouver: Pacific Educational Press.

Johnston, I., Bainbridge, J., \& Shariff, F. (2007). Exploring issues of national identity, ideology and diversity in contemporary Canadian picture books. Papers: Explorations into Children's Literature, (17)2, 75-82. 
King, T. (2003). The truth about stories: A Native narrative. Toronto, ON: House of Anansi Press.

Loh, C. (2009). Reading the world: Reconceptualizing reading multicultural literature in the English language arts classroom in a global world. Changing English, 16(3), 287-299.

Mackey, M. (2009). Stories in and out of school: Texts taught in Grade 10. University of Ottawa. Canadian Society for Studies in Education.

McDonald, M. (2007). The joint enterprise of social justice teacher education. Teachers College Record, 109(8), 2047-2081.

Napoli, M. (2007). Opening children's eyes to the world in which they live - one book at a time: A conversation with Deborah Ellis. Journal of Children's Literature, 22(1), 22-27.

Nodelman, P. (2008). At home on native land: A non-Aboriginal Canadian scholar discussed Aboriginality and property in Canadian double-focalized novels for young adults. In M. Reimer (Ed.), Discourses in children's literature in Canada (pp. 107-128). Waterloo, ON: Wilfrid Laurier University Press.

Pitt, A., \& Britzman, D. (2006) Speculations on qualities of difficult knowledge in teaching and learning: An experiment in psychoanalytic research. In K. Tobin \& J. Kincheloe (Eds.), Doing educational research: A handbook (pp. 379-401). New York: Sense.

Schulte, K. (2012, June 8). Turning Mirrors into Windows [Blog post]. Retrieved from http://sdjsuper.blogspot.ca/2012/06/turning-mirrors-into-windows.html

Van Camp, R., Courtland, M.C., \& Gambell, T. (2010). Richard Van Camp: Aboriginal author, storyteller and teacher. In M.C. Courtland \& T. Gambell (Eds.), Literature, media \& multiliteracies in adolescent language arts (pp. 153-171). Vancouver: Pacific Educational Press.

Wiltse, L. (2013). Historical and Contemporary Perspectives on Cultural, Social, and Political Issues in the Canadian West. In I. Johnston \& J. Bainbridge (Eds.), Reading Multiculturalism: Preservice Teachers explore Identity, Ideology and Pedagogy through Canadian Picture books. (pp. 56-77). Toronto: University of Toronto Press.

Wiltse, L., Johnston, I., \& Yang, K. (2014). Engaging students with social justice through teaching Aboriginal Canadian Literature. Changing English, 21(3), 264277.

Wolf, D., \& DePasquale, P. (2008). Home and native land: A study of Canadian Aboriginal picture books by Aboriginal authors. In M. Reimer (Ed.), Home words: Discourses in children's literature in Canada (pp. 87-105). Waterloo, ON: Wilfrid Laurier University Press.

Wolk, S. (2009). Reading for a better world: Teaching for social responsibility with young adult literature, Journal of Adolescent \& Adult Literacy, 52(8), 664-673. 


\section{Children's Literature Cited}

Children of LaLoche \& Friends. (1990). Byron through the seasons. Saskatoon: Fifth House Publishers.

Cooper, J. (1993). Someone smaller than me. (A. Padlo, Illustr.). Iqaluit, Nunavut: Baffin Divisional Board of Education.

Ellis, D. (2004). The heaven shop. Markham, ON: Fitzhenry \& Whiteside.

Highway, T. (2001). Caribou song. (B. Deines, Illustr.). Toronto, ON: HarperCollins Publishers.

Highway, T. (2002). Dragonfly kites. (B. Deines, Illustr.). Toronto, ON: HarperCollins Publishers.

Highway, T. (2003). Fox on the ice. (B. Deines, Illustr.). Toronto, ON: HarperCollins Publishers.

Ingalls Wilder, L. (1953). Little house on the prairie. (G. Williams, Illustr.). New York, NY: HarperCollins.

Jordan-Fenton, C., \& Pokiak-Fenton, M. (2010). Fatty legs: A true story. Vancouver: Annick Press.

Littlechild, G. (1993). This land is my land. San Francisco, CA: Children's Book Press.

Loewen, I. (1993). My kokum called today. (G. Miller, Illustr.). Winnipeg, MB: Pemmican Publications Inc.

Sanderson, E. (1990). Two pairs of shoes. (D. Beyer, Illustr.). Winnipeg, MB: Pemmican Publications Inc.

Smith, C. L. (2000). Jingle dancer. (C. Van Wright \& Y. Hu, Illustr.). New York: Morrow Junior Books.

St. Pierre, P. (1965). The boss of the Namko drive: A story from Cariboo country. Toronto: The Ryerson Press.

Waboose, J. B. (1997). Morning on the lake. (K. Reczuch, Illustr.). Toronto, ON: Kids Can Press.

Yee, P. (1996). Ghost train. (H. Chan, Illustr.). Vancouver/Toronto, BC/ON: Groundwood/Douglas \& McIntyre.

Yep, L. (1989). Rainbow people. New York: HarperTrophy.

\section{Endnotes}

${ }^{1}$ In her speech, Aldana uses this metaphor as presented by Elisa Bonilla, former director of educational materials at the Mexican Ministry of Education (SEP) of Mexico, in her address to the IBBY congress in Macau, 2006.

${ }^{2}$ In this paper, I use the term Aboriginal, which is inclusive of the Inuit, First Nations (formerly Indian), and Métis peoples of Canada, in a general sense. At other times, I use the term that is most appropriate for the particular context that I am addressing (i.e. First Nations or Indian).

${ }^{3}$ All names have been changed.

${ }^{4}$ For more information on this national study, Preservice Teachers' Perspectives on Canadian Identity and their Understandings of Ideology in Multicultural Picture Books please see Wiltse (2013). 
${ }^{5}$ The Heritage Fair Program is a multi-media educational program developed to increase awareness and interest in Canadian history, unique community events and/or family culture.

${ }^{6}$ For a more detailed description of this project, please see Wiltse, Johnston and Yang (2014).

\section{Author Biography}

Dr. Lynne Wiltse is an Associate Professor in the Department of Elementary Education at the University of Alberta. She teaches courses in the areas of language and literacy and children's literature. Her research interests include minority language education, literacy pedagogy, multicultural children's literature, sociocultural theory, teacher education and qualitative methodologies. 